UNITED STATES DEPARTMENT OF THE INTERIOR

GEOLOGICAL SURVEY

Distribution and Costs of Landslides in San Diego County, California,
During the Rainfall Years of 1978-79 and 1979-80
by
Clement F. Shearer, 1 Fred A. Taylor, ${ }^{2}$ and Robert W. Fleming 3

Open-File Report 83-582

This report is preliminary and has not been reviewed for conformity with U.S. Geological Survey editorial standards and stratigraphic nomenclature.

IUSGS, Reston, VA

2USGS, Men10 Park, CA

3USGS, Denver, CO 


\section{CONTENTS}

Page

Purpose........................................................ 1

Map of landslides in San Diego County............................ 1

Background.................................................... 2

Previous studies......................................... 2

San Diego County landslides..................................... 6

Area studied............................................... 6

Reporting period........................................ 6

Categories of damage costs............................... 7

Method of obtaining cost of damage information.................. 7

Sources of information.................................... 7

Problems encountered in obtaining data....................... 9

Costs of landslide damage in San Diego County.................... 9

Tax loss............................................... 12

Reducing the costs of landslide damage......................... 12

References cited.......................................... 14

\section{ILLUSTRATIONS}

Page

Figure 1. Annual rainfall and accumulated departure from mean annual rainfall 1800-1981 at San Diego, Calif.................. 4

2. Distribution of 1978-80 landslides in each of nine categories based upon the total costs of damage........... 11

3. Distribution of costs of landslide damage in four geographic areas of the United States.................. 13

\section{TABLES}

Page

Table 1. Costs of landslides damage in five metropolitan areas of the United States................................... 5

2. Public and private sources of data relating to the costs and locations of landslides in San Diego County, California...... 8

3. Costs of landslide damage in San Diego County, rainfall years $1978-80$ 


\title{
DISTRIBUTION AND COSTS OF LANDSLIDES IN SAN DIEGO COUNTY, CALIFORNIA, DURING THE RAINFALL YEARS OF 1978-79 AND 1979-80
}

\author{
by Clement F. Shearer, Fred A. Taylor, and Robert H. Fleming \\ PURPOSE
}

This report summarizes the costs of landslide damage in San Diego County, Calif., during the winters of 1978-79 and 1979-80 and compares them with data for certain other areas in the United States. Information about the costs of damage and the benefits of measures to reduce landslide damage highlights the significance of both the damages to affected communities and the potential damages to many communities throughout the Nation. Also, such comparison strongly suggests that in many instances allocation of funds for disaster prevention, rather than for repair and restoration, is cost efficient.

The principal purposes, then, of this report are to increase public awareness of landslide damage, to encourage better documentation of 1 ands 1 ide occurrences and costs, and to stimulate wider and better debate among public officials on the relative merits of various disaster prevention schemes.

\section{MAP OF LANDSLIDES IN SAN DIEGO COUNTY}

This open-file report is the text to a map which is to be published as an MF-series map by the U.S. Geological Survey. The report is being released in this form because of interest in the costs of damage and publication of the map is sometime away. The map shows locations of those landslides which occurred in rainfall years 1978-79 and 1979-80 and damaged manmade structures. The map also shows locations of landslides taken from a San Diego County landslide map compiled by Lough (1974).

The landslides shown on the map by Lough (1974) include all previously failed slopes, whether damaging or not and without regard to their historical activity. He first plotted those landslides that were identified in published sources and landslides that were personally known to him. The map was then circulated to geotechnical firms in the area and other landslides were added (C. F. Lough, oral commun, 1983). The map has not been updated since 1974, so a gap exists in the data between 1974 and the period covered by our survey. Note also that the compilation by Lough (1974) shows the locations of landslides in coastal bluffs. We did not include coastal bluff problems because we could not obtain cost information and there was some question about separation of damages caused by erosion from damages caused by landsliding.

Three areas on Lough's map compilation show notable concentrations of landslides. These are the coastal areas generally to the west of I-805 and north of State Highway 274 to Del Mar, southwestern Poway, and the Fletcher Hills area. By comparison, landslides in these areas during 1978-80 occurred mostly in the southern part of the coastal area, they were nearly absent near Poway, and of a continuing nature in the Fletcher Hills area.

Because the locations of the landslides of 1978-80 are only generally known, it is not possible to directly compare landslide locations with locations of previous landsliding or particular bedrock formations. However, some significant landslides apparently occurred in the Friars Formation, a unit that was noted as slide-prone in the Seismic Safety study for the City of San Diego (Woodward-Gizienski \& Associates and Leighton \& Associates, 1974). of the nine landslides that caused damages in excess of $\$ 1$ million, seven occurred in the Friars Formation and two in the Santiago Formation in the northern part of San Diego County. 


\section{BACKGROUND}

Landslides are among the most costly natural hazards in the United States. A recent national survey of 1 andslide damages placed the annual costs in excess of $\$ 1$ billion per year (Schuster, 1978). For the 50-year period 1925-75, the cost of damages from two types of ground failures, 1 andsi ides and subsidence, was more than triple that of the combined damages from earthquakes, floods, tornadoes, and hurricanes (Jahns, 1978). Landslide hazards and damages are widespread throughout the United States, but the most severe are in the West Coast region, the Rocky Mountains, northern Great Plains, and the Appalachian Mountains and Plateau (Radbruch-Hall and others, 1976).

Landslides are downward and outward movements of slope-forming materials composed of any combination of natural rock, soil, or artificial fill. Although geologists commonly subdivide landslides into falls, topples, slides, spreads, or flows (Varnes, 1978), such differentiations are not needed for this report.

\section{Previous Studies}

Landslides have caused extensive damage in southern California over the past 60 years. However, the damage record is incomplete and the available cost estimates are generally only for private property and may al so include damage from erosion, flooding, and sedimentation (see, for example, Jahns, 1969a; S1osson and Krohn, 1979). For much of the United States, Iandslide damages generally are relatively constant from year to year, with greatly increased damages during years of historically exceptional storms, such as Hurricane Camille in Virginia in 1969 and Hurricane Agnes in Pennsylvania in 1972.

In coastal California the geology--commonly consisting of weak, sheared, and broken rocks on steep slopes--and the climate, in which rainfall is concentrated during winter months combine to create ideal conditions for the formation of landsijes. During relatively dry years, newly formed landslides are uncommon. Years of near-average total rainfal1, however, may produce extensive damages from soil slips and debris flows if a high-intensity storm follows a wetting of the slope materials by antecedent rainfal1. And, during years of large amounts of rainfall, including both high-intensity storms and prolonged rainfall, both deep-seated landslides and shallow soil slips and debris flows occur. Therefore, to obtain meaningful estimates of annual costs of landslide damage in California, the costs should be averaged over several years to include years without appreciable damage.

The years which received abnormally intense rainstorms or large total rainfall are the focus of published accounts of damages. For example, a storm in January 1952 caused estimated damages of $\$ 7.5$ miliion in the City of Los Angeles (Jahns, 1969a). Slosson (1969) reported damage of $\$ 7.5$ million in 1962 and more than $\$ 6$ million in 1969 in the City of Los Angeles. Slosson and Krohn (1979) reported damages of $\$ 50$ million in the City of Los Angeles for the severe rainy season in early 1978. Studies of costs of landslide damage in the San Francisco Bay region are reviewed in Fleming and Taylor (1980).

Many published estimates of the costs of landslide damage in California have been for the destruction caused by individual landslides. For example, Merriam (1960) attributed $\$ 10$ million damage to the Portuguese Bend landslide in Palos Verde Hills. More recently, the Bluebird Canyon landsl ide in Laguna Beach caused an estimated loss of about $\$ 15$ million to private property (Tan, 1980). 
In California, where both short-term, intense storms and above-average annual rainfall produce landslides, there are two additional factors that have not been fully evaluated but influence the occurrence of landslides. First is the effect of modifying the topography by cutting and filling on slopes. McGill (1982), in a comparison of historically active landslides with prehistoric landslides in the Pacific Palisades area of Los Angeles, noted that the number of moderately thick to deep-seated landslides that have occurred in the last 60 years apparently is comparable to the number that occurred prehistorically in the preceding thousands of years. The increased landslide activity is at least in part the result of hillside development over the past 60 years.

The second factor is the effect of an apparent long-term dry period that began about the same time as the post-World War II period of intensive land development. Rainfall data for the City of San Diego plotted in figure 1 for the period 1800-1980 show both annual rainfall and accumulated departures from mean annual rainfal1. The graph of accumulated departures from mean annual rainfall suggests cycles of extended drier than normal years and wetter than normal years. Note that from about 1946 through 1977 there was an accumulating deficit of moisture. Above average rainfall since 1977 has removed 16.5 in. $(42 \mathrm{~cm})$ of the $37-i n . ~(94-\mathrm{cm})$ deficit. A continuation of above-average precipitation will produce high ground-water levels that are unprecedented with respect to modern development on slopes. Jahns (1969b) discussed the ramifications of a similar cyclic moisture curve for Los Angeles and predicted that a greater incidence of landsliding will accompany a continuation of surplus annual rainfall.

The U.S. Geological Survey has conducted surveys of costs of landslide damage in the urban areas of the San Francisco Bay region, Hamilton County, Ohio, and Allegeheny County, Pa. (Fleming and Taylor, 1980). Costs of landslide damage for the City of Los Angeles have been reported by Slosson (1969) and Slosson and Krohn (1979). The costs are summarized in table 1 and the method of obtaining the data and determining costs are discussed in Fleming and Taylor (1980). In general, the data reveal that the costs of landslide damage are larger than might have been anticipated and the annual costs in some other parts of the United States are at least equal to those in Cal ifornia.

The annual per capita costs of landslide damages shown in table 1 were obtained in different ways. For Allegheny County, Pa., the average annual cost for the 7-year period, 1970-76, was divided by the estimated population of the county. Similarly, for Hamilton County, Ohio, the average annual cost for the 6-year period, 1973-78, was divided by the estimated population of the county. However, data from the San Francisco Bay region were obtained for rainfall years 1968-69 and 1972-73, and because damages in Cal ifornia are concentrated in years of abnormally large rainfall, landslide damage for the 2 years was estimated to represent a 10-year period. Therefore, the sum of total damages for the 2 years was divided by 10 and by the total population of the nine-county San Francisco Bay region. For the City of Los Angeles, data reported by Slosson (1969) for the rainy season of 1968-69 and by Slosson and Krohn (1979) for the rainy season of 1977-78 of $\$ 6$ million and $\$ 50$ million, respectively, apply only to damage to private property. Experience from other areas (fig. 3 ) revealed that the public costs of landslide damages range from about 17 percent (San Diego County) to about 73 percent (Al legheny County, $\mathrm{Pa}$.$) of the total costs of damages. If public costs of damage in Los Angeles$ are 40 percent of the total, the total damages for the City of Los Angeles for 1968-69 are $\$ 10$ million and for 1977-78 are $\$ 83$ million. Assuming the 


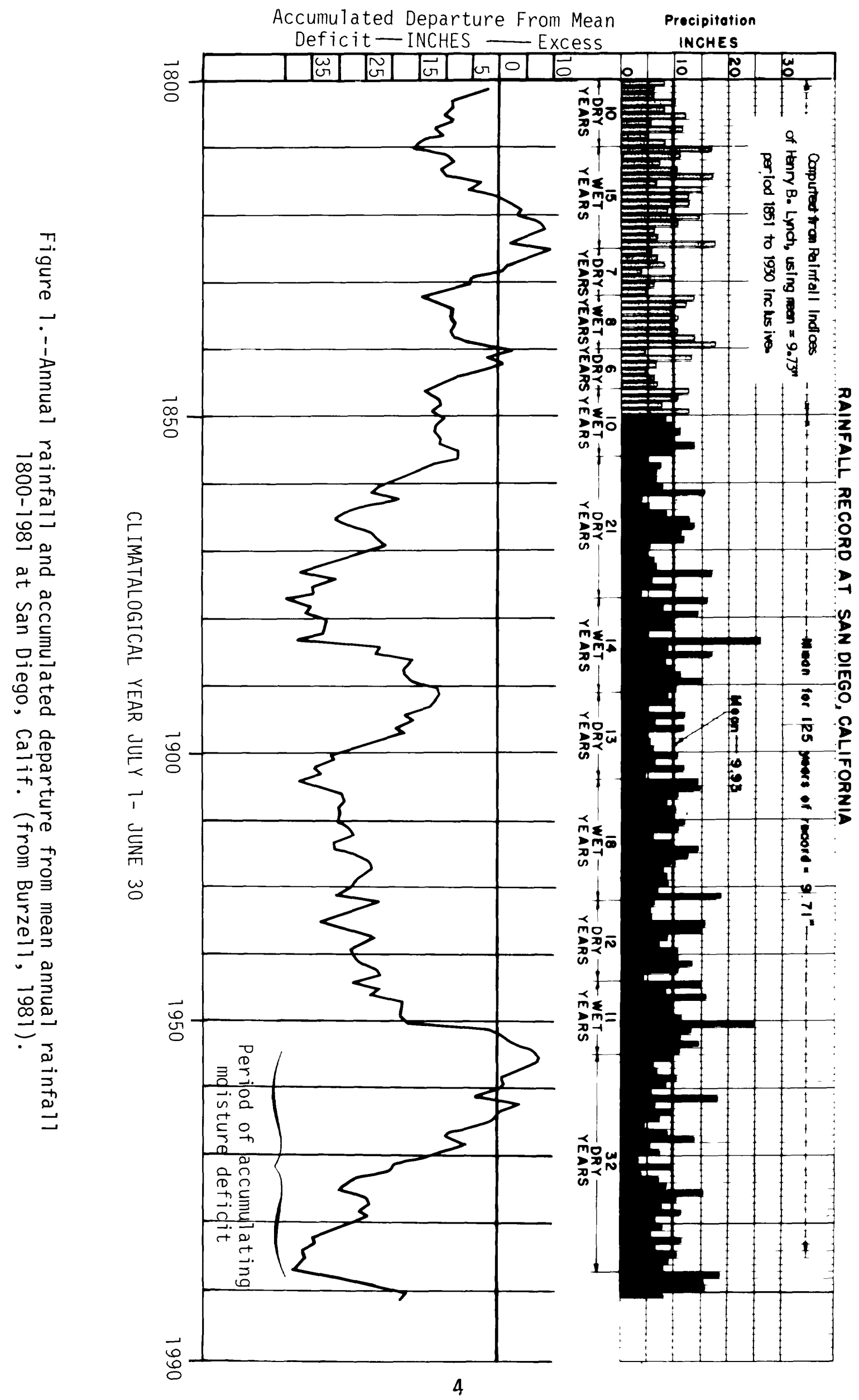


Table 1.--Costs of landslide damage in five metropolitan areas of the United States

\begin{tabular}{|c|c|c|c|c|c|}
\hline Location & $\begin{array}{l}\text { Years of } \\
\text { record }\end{array}$ & $\begin{array}{l}\text { Total } \\
\text { cost }\end{array}$ & $\begin{array}{l}\text { Average } \\
\text { annual } \\
\text { cost }\end{array}$ & $\begin{array}{l}\text { Annual } \\
\text { per } \\
\text { capita } \\
\text { cost }\end{array}$ & $\begin{array}{l}\text { Adjusted } \\
\text { per } \\
\text { capita } \\
\text { cost2 }\end{array}$ \\
\hline \multicolumn{6}{|l|}{ Allegheny County, $\mathrm{Pa}$. } \\
\hline \multicolumn{6}{|c|}{ Hamilton County, Ohio } \\
\hline (includes Cincinnati)--- & $1973-78$ & $30,680,000$ & $5,110,000$ & 5.80 & 8.80 \\
\hline San Francisco Bay region-- & $\begin{array}{l}1968-69 \\
1972-73\end{array}$ & $59,000,000$ & $5,900,000$ & 1.30 & 2.80 \\
\hline City of Los Angeles------ & $\begin{array}{l}1968-69 \\
1977-78\end{array}$ & $93,000,000$ & $9,300,000$ & 1.30 & 1.80 \\
\hline San Diego County- & $1978-80$ & $19,000,000$ & $1,900,000$ & 1.05 & 1.05 \\
\hline
\end{tabular}

1 Years of record for Allegheny County and Hamilton County refer to calendar years, a 7-year period and 6-year period, respectively. The California data refer to rainfall years, for example 1978-80 is a 2-year period.

2 The adjusted per capita costs have been quoted in terms of 1980 dollars by adjusting the costs of damages for each year of data into 1980 dollars.

3 The study in Allegheny County included interviews with only a few of the potential sources of landslide damage information. Furthermore, several agencies and consultants were unwilling or unable to provide information even though it was known that damage had occurred within their jurisdictions. Therefore, the data are assumed to reflect only about half of the total actual damages. The average annual cost has been adjusted to $\$ 4$ million to account for the missing information. 
landsliding represents a 10-year period of damage, the average annual per capita cost of damage was obtained by dividing the sum of costs for 1968-69 and 1977-78 by 10, and by the population of the City of Los Angeles. Similarly, for San Diego County, the rainfall years 1978-79 and 1979-80 were assumed to reflect a 10-year period of damages. The sum of costs was divided by 10 and by the population of San Diego County to obtain annual per capita cost.

In table 1, annual per capita costs of damage have been adjusted to 1980 dollars by multiplying by a factor of inflation provided by the Consumer Price Index (International Monetary Fund, 1981, p. 440-441). In reporting annual per capita costs of damage, we knowingly introduce some distortions in the data, but it is desirable to adjust cost figures to a common basis in order to make crude comparisons of damage in different parts of the United States. In all these data, per capita costs include not only costs borne by inhabitants of a given metropolitan area, but also public costs shared by the inhabitants of larger governmental jurisdictions (State and Federal). The most severe burden of landslide damage is borne by private property owners because they have no means to spread the losses to a larger segment of the population. Landslide insurance is not generally available, and governmental programs to assist victims of disasters do not apply to landslide damages unless the damages occur in conjunction with a declaration of disaster for an earthquake, flood, or severe storm. In San Diego County in 1978-80, 76 percent of the damages ( $\$ 14.4$ million) were to private property.

\section{SAN DIEGO COUNTY LANDSLIDES}

\section{Area Studied}

The study of damage costs covers $4,060 \mathrm{mi}^{2}\left(10,515 \mathrm{~km}^{2}\right)$ of the 16 incorporated cities and the unincorporated area of San Diego County. Excluded are the coastal bluff areas of the county and the U.S. Marine Corps facility at Camp Pendleton, which is not available for public use or development.

San Diego County contains extensive coastal bluffs which have been severely damaged by coastal erosion, raveling, surface erosion, and landsliding. Because the damage is attributable to several different processes including landsliding, no costs are included in this summary. Twelve landslides were reported as having occurred in the coastal bluffs in rainfall years 1978-80, but no damage estimates were obtained and their locations are not shown on the map. However, landslides in coastal bluffs in San Diego County up to 1974, as compiled by Lough (1974), are shown on the map.

\section{Reporting Period}

The costs of landslide damage were obtained for the rainy seasons of 1978-79 and 1979-80. Because the various information sources keep records differently, and some of them have difficulty assigning expenditures to specific dates of landslides, some of the costs of damage may have been applied to landslides which occurred in 1978 before the rainy season and in 1980 following the rainy season. The amount of any such inclusions, if any, is small. 


\section{Categories of Damage Costs}

Damage costs are divided into public, private, and miscellaneous categories. "Public costs" are dollars spent or lost by local, county, State or Federal governments. These costs are ultimately paid by the taxpayers and partly are spread over a much larger base of taxpayers than within the area of study. "Private costs" of damages are expenses or losses to individuals, businesses, and other nongovernment groups. Other costs which cannot be accurately classified as public or private are termed "miscellaneous costs." For San Diego County, miscellaneous costs include litigation costs where responsibility is disputed between the public and private sectors, cases where the source of cost information did not provide a specific location of damages, and a few cases, principally involving service companies, where the sources of information asked that their losses be lumped with other data to protect their confidentiality.

Damage estimates are of money spent on repairs, value of property lost due to damage, and the amount required to restore an area to a functional level. The amount spent does not necessarily indicate the total damage which has occurred. In some instances the problem is only partially corrected. In other cases an agency may decide the repair work is becoming too costly and cease its funding, thus allowing only partial restoration to be completed. The estimate for repair of one area of extensive landsliding, which would cost about $\$ 1.7$ million, was not included in this compilation because it is not clear who would fund the repair work or whether the repairs will ever be made.

Costs of damage in this report generally do not reflect damage which occurred during land development or construction. In such instances, an undetermined amount may be lost due to time spent in site repair or removal of already completed structures.

\section{Method of Obtaining Cost of Damage Information}

Information on the costs of damage and general locations of landslides was obtained from interviews of officials in governmental agencies and of various private sources that could be expected to have access to such data. A more extensive account of the method used is described in Fleming and Taylor (1980). In most cases only one person per public agency or private source was contacted and the information may not be complete. If a particular estimate did not appear reasonable with respect to the description of damages, a second estimate was obtained from another person in the same organization. In all cases, the costs of damage were provided by the sources and, by obtaining locations of the damages, we were able to discard data that would be duplicated by other sources. If a range of damage costs was provided as an estimate, the mean value was used in reaching a total for a particular landslide. In general, the method attempts to develop minimum figures through discarding data that would be duplicated or when damages are difficult to apportion to different hazards.

\section{Sources of Information}

The public and private sources of information on the locations and costs of landslide damages are listed in table 2. Most of the information on costs of damage experienced by the private sector was provided by 13 private consulting firms. 
Table 2.--Public and private sources of data relating to the costs and locations of landslides in San Diego County, California

\begin{tabular}{|c|c|c|c|c|}
\hline & Local & $\begin{array}{c}\text { Regional } \\
\text { or } \\
\text { county }\end{array}$ & State & Federa 1 \\
\hline \multicolumn{5}{|l|}{ Public sources: } \\
\hline Assessor's office- & ---- & $x$ & $-\cdots$ & ------ \\
\hline Building Inspectors- & $x$ & $x$ & ---- & ----- \\
\hline Cal ifornia Coastal Commission- & $-\cdots--$ & ----- & $x$ & $-\cdots--$ \\
\hline Disaster Preparedness Office & ---- & $x$ & $-\cdots-$ & $-\cdots--$ \\
\hline Engineer-ar & $x$ & $x$ & ---- & $-\cdots--$ \\
\hline Flood Control & $-\cdots-$ & $x$ & $-\cdots$ & $-\cdots$ \\
\hline Geologist-n & $-\cdots-$ & $x$ & $-\cdots$ & $x$ \\
\hline Irrigation District- & $-\cdots$ & $x$ & $-\cdots$ & \\
\hline Parks and Recreation & $x$ & $x$ & $-\cdots-$ & $-\cdots$ \\
\hline Planning and Land Use- & $-\cdots-$ & $x$ & ---- & \\
\hline Public Works & $X$ & $x$ & $-\cdots-$ & --- \\
\hline Sanitation Department & $x$ & $-\cdots--$ & $-\cdots$ & ----- \\
\hline Sanitation District & $-\cdots-$ & $X$ & $-\cdots-$ & $-\cdots$ \\
\hline Smal1 Business Administration- & --- & $-\cdots-$ & --- & $x$ \\
\hline Special Projects- & ---- & $x$ & ---- & $-\cdots--$ \\
\hline Street Maintenance & $x$ & ----- & ---- & --- \\
\hline Transportation Department & $-\cdots--$ & $x$ & $\mathrm{X}$ & ---- \\
\hline University- & $-\cdots$ & $-\cdots-$ & $x$ & $-\cdots--$ \\
\hline Water Department-n & $x$ & $-\cdots-$ & $-\cdots$ & $-\cdots--$ \\
\hline Water District-n & $-\cdots$ & $x$ & $-\cdots-$ & $-\cdots--$ \\
\hline \multicolumn{5}{|l|}{ Private sources: } \\
\hline \multicolumn{5}{|l|}{ Consulting Engineers and Geologists } \\
\hline \multicolumn{5}{|l|}{ Private Corporations } \\
\hline \multicolumn{5}{|l|}{$\begin{array}{l}\text { Publically owned utilities and services } \\
\text { companies. }\end{array}$} \\
\hline \multicolumn{5}{|l|}{ Communications Companies } \\
\hline \multicolumn{5}{|l|}{ Sewerage Companies } \\
\hline Water Companies & & & & \\
\hline Gas and Electric Companies & & & & \\
\hline
\end{tabular}




\section{Problems Encountered in Obtaining Data}

The major problems encountered in obtaining cost information are (a) lack of or incomplete records, (b) problems finding the information, (c) confidentiality of data, and (d) information that does not separate landslide damage from other types of damage such as erosion or flooding. For these reasons, the authors believe that the actual costs of landslide damage in San Diego County are higher than we documented. Until more complete data are available, however, the documented costs provide conservative estimates of the total costs of damage and numbers of landslides.

Another problem concerns the locations of individual landslides on the map. Private sources of information were reluctant to release data on maps of a scale which would reveal the precise location of a client's project. Locations provided by public sources of information were on maps of various scales and some were only generally defined. The locations of the landslides on the map for which we obtained costs of damage data have been deliberately generalized to protect confidentiality of sources and to avoid giving the impression that the locations are better known than they actually are. There definitely are more landslides than indicated on the map.

An indication of the abundance of landslides in San Diego County may be gained from comparison with a more detailed study by Weber (1982). He conducted mapping at a scale of $1: 24,000$ of an $8-\mathrm{mi}^{2}\left(220-\mathrm{km}^{2}\right)$ area of the north-central coastal area of San Diego County. The map area contains locations of more than 21 "ancient and pre-recent historical landslides," including some depicted as possible or probable, and 32 slope failures by landsliding or erosion that mostly occurred in 1980. In the same area, we were able to obtain information on costs of damages of 13 landslides. Of the 32 landslides reported by Weber (1982) as products of the 1980 storms, more than 20 were described as minor problems, erosional rilling, and (or) surficial slumping and sloughing. Therefore, this map does not accurately portray all the landslides that occurred in San Diego County during these 2 years but it is apparently a reasonable approximation of those which produced significant damage.

\section{Costs of Landslide Damage in San Diego County}

San Diego County experienced major damage from storms in 1978-79 and 1979-80, as did neighboring areas of Los Angeles and Orange County (Tan, 1980; Weber and others, 1979; Weber, 1980; Hsu, 1982). One hundred-twenty landslides were reported to have occurred in San Diego County during these 2 years with damage totaling approximately $\$ 19$ million. Rainfall for the rainy seasons of 1978-79 and 1979-80 was 14.82 and $15.61 \mathrm{in}$. (37.6 and $39.6 \mathrm{~cm}$ ), respectively (U.S. Department of Commerce, 1980), compared to a 125-year average $(1850-1975)$ of $9.71 \mathrm{in} .(24.7 \mathrm{~cm})$. The frequency of storms of the intensity experienced in 1977-78 and in 1979-80 has been estimated by the San Diego County Flood Control District to recur every 20-25 years (Carey Stevenson, oral commun., 1981). The costs of damage for the rainfall years 1978-80 should be prorated to reflect the lack of landsliding in relatively dry years. The above average rainfall of 1977-78 perhaps contributed to some landsliding in 1978-80. Thus, the three consecutive rainfall years of above average rainfall may be a very unusual period for compilation of damages. For purposes of comparison of costs of landslide damage in San Diego County with that in other areas (see table 1), we have somewhat arbitrarily assumed that the aggregate of losses for the 2-rainfall-year period is representative of an aggregate of losses for a 10-year period. 
The reported costs of damage for the three categories, public, private, and miscellaneous, is summarized in table 3. Data are given for the 2-rainfall-year period of 1978-80 and the 1-year estimated cost is simply half the total.

Table 3.--Costs of landslide damage in San Diego County,

rainfal1 years $1978-80$

Public costs: 1

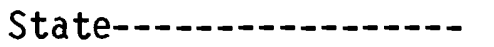

$\$ 411,000$

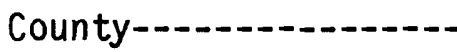

800,000

Cities

$1,907,000$

Tax loss--.--

248,000

Total

$\$ 3,166,000$

Private costs-------- $14,431,000$

Miscellaneous-...-...- 31,396,000

Litigation, unspeci-

fied locations and

service companies.

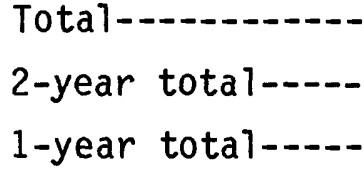
$\$ 15,827,000$ $\$ 18,993,000$ $\$ 9,496,500$

\footnotetext{
1 No Federal costs were reported by the two sources contacted.

2Documented for one landslide, prorated and rounded for all others.

${ }^{3}$ In addition to the amount listed, several pending court cases with multimillion dollar amounts involved are not included.
}

Figure 2 shows the numbers of landslides that produced private and public damages in different ranges of damage costs for the 120 landsiides. Seventy percent of the total damage was associated with the 16 most costly landslides. The 10 landslides with costs of repair of less than $\$ 5,000$ each were all slipouts of streets and highways. Slipout is a term used by some to describe an area in which a section of roadway has moved downward in response to underlying material slipping out from under the roadway. Previously studied areas in other parts of the United States (Fleming and Taylor, 1980) have had one or possibly two landslides in the million-dollar range. San Diego County has nine such troublesome areas.

The average cost of damage per landslide was about $\$ 160,000$. Some landslides affected more than one residential unit. The average cost for each residence damaged or destroyed was about $\$ 85,000$. 


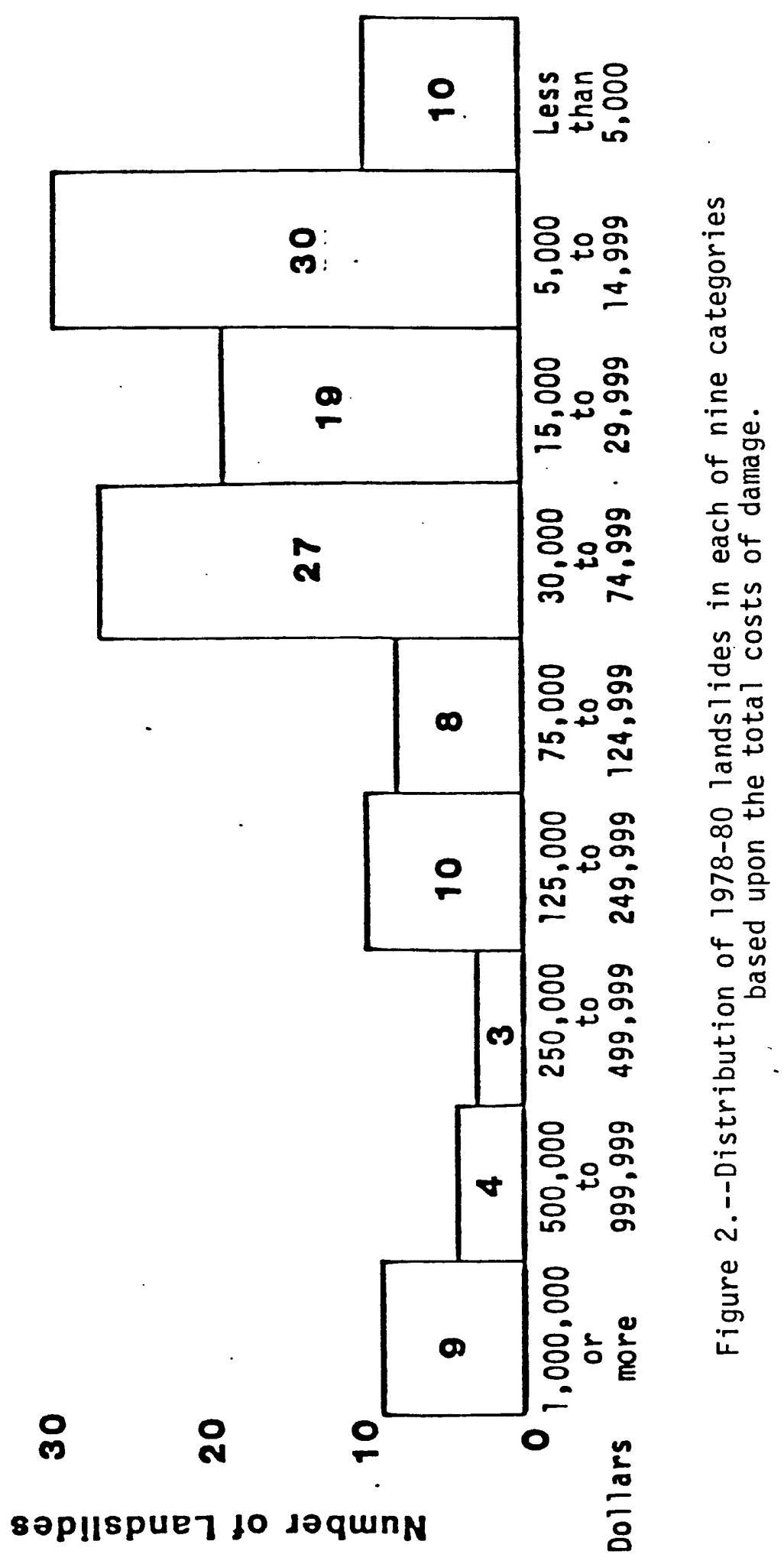


Figure 3 shows graphically the breakdown of the amount of public, private, and miscellaneous costs of damage for Allegheny County, Hamilton County, the nine-county San Francisco Bay region, and San Diego County. Note the disproportionately large damage in the private sector of San Diego County compared to other areas of the United States.

\section{Tax Loss}

In San Diego County during rainfall years 1978-80, nine landslides each resulted in damage or restoration costs of $\$ 1$ million or more. Six of these were entirely on private property which is taxable, and two caused damage to both public and private property. Tax records for 13 parcels of 1 and affected by one such slide show the county to be receiving 74 percent less annual tax revenue from these properties since the landsliding. This loss of public funds is currently about $\$ 5,400$ total per year for the parcels in this one landslide. Further, these properties may be permanently lost from the tax rolls. Tax loss was not determined for the seven other major landslides involving private property; however, if the loss for each is only one-half that of the landslide involving 13 parcels, the loss is an additional $\$ 18,900$. The loss for the more numerous, but less costly, landslides was not calculated. For many of these damages, tax assessments are depreciated for 1 year and raised to full value the next.

\section{REDUCING THE COSTS OF LANDSLIDE DAMAGE}

The goal of efforts to determine the costs of damage from landslides in the United States is to reduce such costs through measures designed to prevent landsliding or to mitigate damage that does occur. The California Division of Mines and Geology has estimated that landslide damage in California will average more than $\$ 330$ million annually during the years from 1970 to 2000 if loss reduction practices in effect in 1970 are not improved (Alfors and others, 1973). A wide variety of engineering alternatives is available to correct landslide problems once they have occurred; however, the engineering solutions are usually very expensive, and the costs of repair can exceed the intrinsic value of the property being repaired. Local governments, through planning and regulations, have various options to reduce the costs of landslide damage. Erley and Kockelman (1981) have summarized methods that can be used to avoid landslide hazards and reduce damage.

The technology is available to greatly reduce losses from landslides by avoiding or preventing them. Leighton (1976) estimated that in California a reduction in damaging failures of 95-99 percent is technically attainable through the use of three levels of investigation--regional, tract or community, and site--with progressively greater detail being obtained in the investigations of the smaller areas. The seismic safety study for the City of San Diego (Woodward-Gizienski \& Associates and Leighton \& Associates, 1974), geologic maps of the San Diego metropolitan area by Kennedy and Peterson (1975), published summaries of landslide and other geologic hazards in San Diego County (Hart, 1979; Ross and Dowlen, 1973; Abbott and Victoria, 1977; and Abbott and Elliott, 1979), and other available references provide the San Diego area with a good, regional data base for reducing landslide damages.

This study does not attempt to evaluate local programs to reduce damages. It should be noted, however, that in addition to the technical studies cited above, both the City and County of San Diego have adopted grading regulations similar to regulations that are effective in other areas, 
Numbers are percent of the total

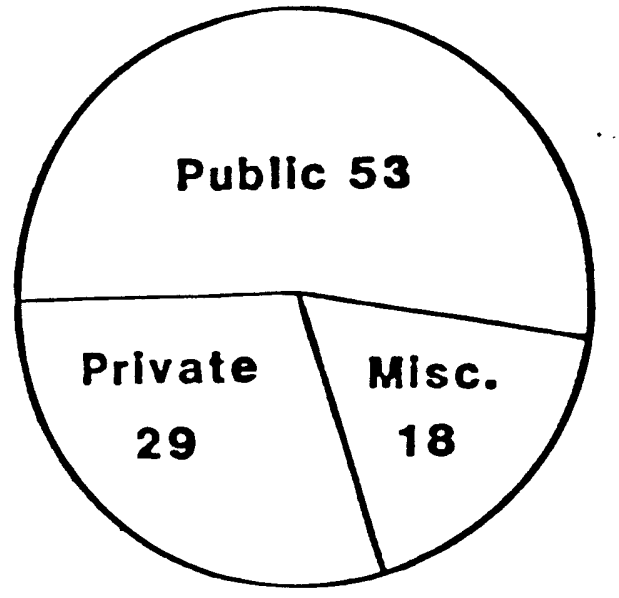

San Francisco Bay Region, California

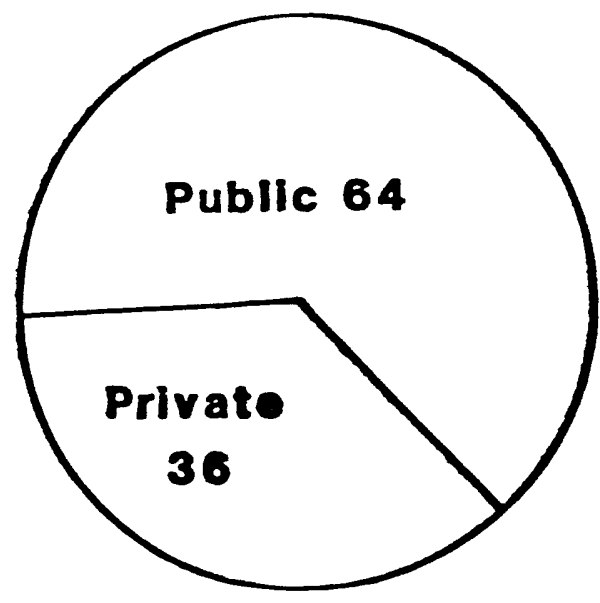

Hamliton County. Ohio

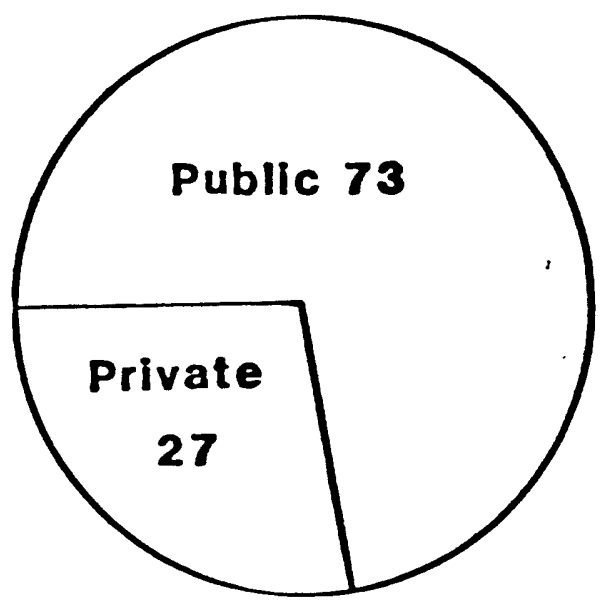

Allegheny County, Pennsylvania

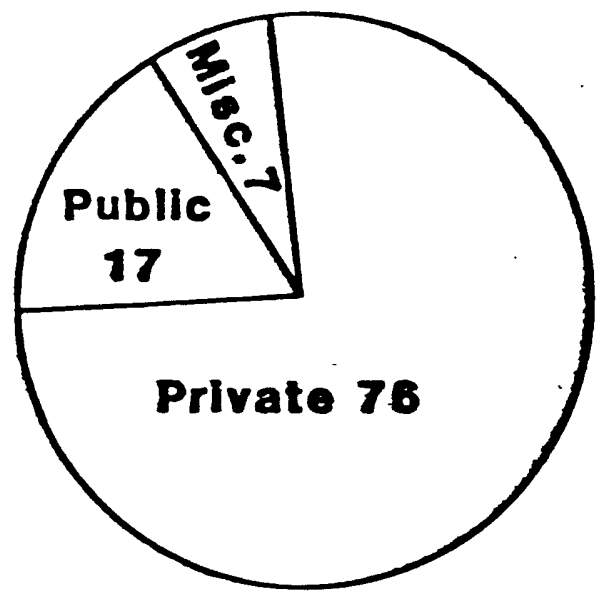

San Diego County, Callfornia

Figure 3.--Distribution of costs of landslide damage in four geographic areas of the United States. 
including the City of Los Angeles. It is likely that the damage reduction activities in San Diego County are preventing or avoiding many slope failures.

\section{REFERENCES CITED}

Abbott, P. L., and Elliott, W. J., eds., 1979, Earthquakes and other perils, San Diego region: San Diego Association of Geologists, Geological Society of America Annual Meeting Field Trip, San Diego, 1979, 227 p.

Abbott, P. L., and Victoria, J. K., eds., 1977, Geologic hazards in San Diego; earthquakes, landslides and floods: San Diego Society of Natural History, $96 \mathrm{p}$.

Alfors, J. T., Burnett, J. L., and Gay, T. E., Jr., 1973, Urban geology-master plan for California; The nature, magnitude, and costs of geologic hazards in California and recommendations for their mitigation: California Division of Mines and Geology Bulletin 198, 112 p.

Burze11, L. R., 1981, Thirty-fifth annual report of authority operations for fiscal year ending June 30, 1981: San Diego County Water Authority, San Diego, Cal ifornia, $85 \mathrm{p}$.

Erley, Duncan, and Kockelman, W. J., 1981, Reducing landslide hazards--A guide for planners: American Planning Association, Planning Advisory Service Report 359, 29 p.

Fleming, R. W., and Taylor, F. A., 1980, Estimating the costs of landslide damage in the United States: U.S. Geological Survey Circular 832, 21 p.

Hart, M. W., 1979, Landslides and debris flows in San Diego County, California, in Abbott, P. L., and Elliott, W. J., eds., Earthquakes and other perils, San Diego region: San Diego Association of Geologists, Geological Society of America Annual Meeting Field Trip, San Diego, 1979, p. $167-182$.

Hsu, E. Y., 1982, Investigation and inventory of slope failures that occurred in 1978 and 1980 in the Los Angeles 7 1/2-minute quadrangle, Los Angeles County, California: California Division of Mines and Geology Open-File Report 82-26LA, 88 p., 2 maps.

International Monetary Fund, 1981, International financial statistics yearbook (English ed.): International Monetary Fund, Washington, D.C. 20431, v . $34,471 \mathrm{p}$.

Jahns, R. H., 1969a, Seventeen years of response by the City of Los Angeles to geologic hazards, in 01 son, R. A., and Wallace, M. M., eds., Geologic Hazards and Public Problems Conference, May 27-28, 1969, Proceedings: U.S. Office of Emergency Preparedness, Region Seven, Santa Rosa, California, p. 283-296. 1969b, California's ground-moving weather: Engineering and Science Magazine, California Institute of Technology, 8 p., March. 1978, Landslides, in Geophysical predictions: Washington, D.C., National Academy of Sciences, p. 58-65.

Kennedy, M. P., and Peterson, G. L., 1975, Geology of the San Diego metropolitan area, California: California Division of Mines and Geology Bulletin 200, 56 p., 6 maps, scale 1:24,000.

Leighton, F. B., 1976, Urban landslides--targets for land-use planning in California, in Coates, D. R., ed., Urban geomorphology: Geological Society of America Special Paper 174, p. 37-60.

Lough, C. F., compiler, 1974, County of San Diego landslide map: San Diego County, Office of Environmental Management, Environmental Development Agency, scale 1:125,000. 
McGill, J. T., 1982, Map showing relationship of historic to prehistoric landslides, Pacific Palisades area, City of Los Angeles, California: U.S. Geological Survey Miscellaneous Field Studies Map MF-1455, scale $1: 4,800$.

Merriam, R. H., 1960, Portuguese Bend landslide, Palos Verdes Hills, California: Journal of Geology, v. 68, no. 2, p. 140-153.

Radbruch-Ha11, D. H., Colton, R. B., Davies, W. E., Skipp, B. A., Lucchitta, Ivo, and Varnes, D. J., 1976, Preliminary landslide overview map of the conterminous United States: U.S. Geological Survey Miscellaneous Field Studies Map MF-771, scale 1:7,500,000.

Ross, Arnold, and Dowlen, R. J., eds., 1973, Studies on the geology and geologic hazards of the greater San Diego area, California: San Diego Association of Geologists Field Trip Guidebook, May 1973, 152 p.

Schuster, R. L., 1978, Introduction, Chapter 1, in Schuster, R. L., and Krizek, R. J., eds., Landslides--Analysis and control: Transportation Research Board Special Report 176, National Academy of Sciences, p. 1-10. Slosson, J. E., 1969, The role of engineering geology in urban planning: Colorado Geological Survey Special Publication 1, p. 8-15.

Slosson, J. E., and Krohn, J. P., 1979, AEG building code review-Mudflow/debris flow damage; February 1978 storm--Los Angeles area: California Geology, v. 32, no. 1, p. 8-11.

Tan, S. S., 1980, Slope failures in Orange County due to 1978 rains: California Geology, v. 33, no. 9, p. 202-205.

U.S. Department of Commerce, 1980, Local climatological data, California: National Oceanic and Atmospheric Administration, National Climate Center, Asheville, North Carolina.

Varnes, D. J., 1978, Slope movement types and processes, Chapter 2, in Schuster, R. L., and Krizek, R. J., eds., Landslides--Analys is $\overline{\text { and }}$ control: Transportation Research Board Special Report 176, National Academy of Sciences, p. 11-33.

Weber, F. H., Jr., 1980, Landsliding and flooding in southern California during the winter of 1979-80: California Division of Mines and Geology Open-File Report 80-3LA, 69 p. 1982, Recent slope failures, ancient landslides, and related geology of the north-central coastal area, San Diego County, California: California Division of Mines and Geology Open-File Report 82-12LA, 77 p., map. Weber, F. H., Jr., Treiman, J. A., Tan, S. S., and Miller, R. V., 1979, Landslides in the Los Angeles region, California--effects of FebruaryMarch 1978 rains: California Division of Mines and Geology Open-File Report 79-4LA, 265 p.

Woodward-Gizienski \& Associates, and Leighton, F. B. \& Associates, 1974, Seismic safety study for the City of San Diego: Unpublished consulting report available for inspection in Planning Department of the City of San Diego, includes 47 maps with explanation, scale 1:9,600. 